\title{
PEMBELAJARAN INKUIRI UNTUK MENINGKATKAN KETERAMPILAN PROSES SAINS CALON GURU FISIKA
}

\author{
Nurussaniah $^{1}$, Eka Trisianawati $^{2}$, Ira Nofita Sari $^{3}$ \\ 1,2,3 Program Studi Pendidikan Fisika Fakultas Pendidikan MIPA dan Teknologi IKIP PGRI Pontianak \\ Jalan Ampera No. 88 Pontianak, Indonesia; e-mail: nurussaniah@gmail.com
}

Diterima: 8 Juli 2017. Disetujui: 8 Oktober 2017. Dipublikasikan: 28 Oktober 2017

\begin{abstract}
Abstrak: Penelitian ini bertujuan untuk mengetahui apakah terdapat perbedaan peningkatan keterampilan proses sains calon guru fisika setelah diterapkan pembelajaran inkuiri dan konvensional. Penelitian ini menggunakan metode eksperimen dengan bentuk quasi eksperimen dan rancangan non-equivalent control group design. Hasil penelitian menunjukkan bahwa peningkatan keterampilan proses sains pada kelas yang diterapkan pembelajaran inkuiri adalah 38,09 sedangkan pada kelas yang diterapkan pembelajaran konvensional adalah 17,86. Hasil uji $t$ independent sampel menunjukkan angka signifikansi yaitu 0,004 lebih kecil dari 0,05 . Hal ini menandakan bahwa $H_{0}$ ditolak dan $H_{a}$ diterima sehingga terdapat perbedaan peningkatan keterampilan proses sains calon guru fisika di kelas yang diterapkan pembelajaran inkuiri dan konvensional. $N$-Gain $(g)$ pada kelas eksperimen adalah 0,65 dengan interpretasi sedang dan pada kelas kontrol adalah 0,27 dengan interpretasi rendah. Perbedaan tersebut menunjukkan bahwa pembelajaran inkuiri mampu meningkatkan keterampilan proses sains guru fisika.
\end{abstract}

Kata kunci: calon guru fisika, inkuiri, keterampilan proses sains

\section{INQUIRY LEARNING TO IMPROVE THE SCIENCE PROCESS SKILLS OF THE PRE-SERVICE PHYSICS TEACHERS}

\begin{abstract}
This study aims to determine the difference in the improvement of science process skills of physics teacher candidates after applied inquiry and conventional learning. This research uses the experimental method with quasi-experimental design and non-equivalent control group design. The results showed science process skills' gain in the classroom applied inquiry learning is 38.09 while in the classroom applied conventional learning is 17.86. The result of the independent sample t-test shows that the significance is 0.004 less than 0.05. This indicates that $H_{0}$ rejected and $H_{a}$ accepted, so there is a difference in the improvement of science process skills of physics teachers in the classroom which is applied inquiry and conventional learning. $N$-Gain $(g)$ in the experimental class is 0.65 with moderate interpretation and in the control class is 0.27 with low interpretation. The existence of such differences indicates that inquiry learning can improve the science physics teacher process skills.
\end{abstract}

○ 2017 Pendidikan Fisika, FTK UIN Raden Intan Lampung

Keywords: pre-service physics teacher, inquiry, science process skills.

\section{PENDAHULUAN}

Pembelajaran fisika akan lebih bermakna jika calon guru terlibat aktif dalam pembelajaran. Selain itu, proses pembelajaran fisika menekankan pada pemberian pengalaman langsung untuk mengembangkan kompetensi agar menjelajahi dan memahami alam sekitar secara ilmiah dan dilaksanakan secara inkuiri alamiah (scientific inquiry) untuk menumbuhkan kemampuan berpikir, bekerja dan bersikap ilmiah, serta mengkomunikasikannya sebagai aspek penting kecakapan hidup (Ertikanto, 2017; Rerung, Sinon, \& Widyaningsih, 2017; Susilo, Wiyanto, \& Supartono, 2012; Syamsu, 2017). Oleh karena itu, pembelajaran fisika sangat menekankan pada hal-hal yang bersifat proses, sehingga penguasaan konsep fisika calon guru tidak hanya berupa hafalan, tetapi mereka juga mampu menerapkan konsep 
yang dimilikinya pada aspek lain (Rerung et al., 2017; Wati \& Fatimah, 2016).

Penguasaan konsep oleh mahasiswa merupakan hal yang sangat penting (Saregar, 2016). Mahasiswa sebagai calon guru diharapkan dapat menerapkan, mengkaji, menelaah dan memecahkan masalah, berpikir logis, berpikir kritis, kreatif, inisiatif, adaptif terhadap perubahan dan perkembangan IPTEK. Hal ini relevan dengan kompetensi pedagogik pembelajaran di LPTK. Oleh karena itu terkait dengan kompetensi pedagogik, pembelajaran di LPTK dituntut untuk dapat mengimplementasikan berbagai perkembangan pendekatan, model, metode, strategi, dan teknik dalam dunia pendidikan, sehingga mahasiswa sebagai calon guru nantinya memiliki pengetahuan agar tidak merasa canggung untuk berkreasi dalam pembelajaran di lapangan (sekolah) (Sohibun, Febriani, \& Maisaroh, 2017). Dengan demikian agar sinergi dengan perkembangan dunia pendidikan dan IPTEK, maka menjadi kewajiban IKIP PGRI Pontianak khususnya Program Studi Pendidikan Fisika mencetak guru yang tidak hanya menguasai kompetensi profesional dalam hal kognitif, namun juga harus diimbangi dengan penguasaan terhadap sikap ilmiah melalui keterampilan proses sains.

Keterampilan proses sains merupakan keterampilan fisik dan mental terkait dengan kemampuan-kemampuan yang mendasar yang dimiliki, dikuasai dan diaplikasikan dalam suatu kegiatan ilmiah (Hardiyanto, Susilawati, \& Harjono, 2015; Komikesari, 2016). Dengan menguasai keterampilan proses sains maka mahasiswa calon guru diharapkan dapat menggunakan proses ilmiah dalam proses penemuan suatu konsep, dan pada akhirnya konsep-konsep yang rumit dan abstrak akan lebih mudah dipahami melalui penjelasan yang konkret (Saregar, Latifah, \& Sari, 2016).
Berdasarkan hasil observasi, pembelajaran yang diterapkan dosen di Program Studi Pendidikan Fisika IKIP PGRI Pontianak cenderung bersifat konvensional. Hal ini berdampak pada tidak optimalnya pengembangan keterampilan proses sains mahasiswa. Oleh karena itu pembelajaran saintifik perlu diterapkan. Salah satu yang memfasilitasi mahasiswa calon guru untuk mencapai indikator keterampilan proses sains menurut pandangan kontruktivis adalah model inkuiri terbimbing (Jannah, Nur, \& Suyono, 2016). Oleh karena itu dengan menerapkan pembelajaran inkuiri diharapkan keterampilan proses sains calon guru fisika dapat meningkat.

Beberapa penelitian telah melihat bahwa terdapat peningkatan dan pengaruh pembelajaran inkuiri pada hasil belajar dan pemahaman konsep (Lestari, Suniasih, \& Putra, 2016; Wahyudin, Sutikno, \& Isa, 2010; Yamin, 2016). Namun pada penelitian ini lebih mendalam akan dilihat keterampilan proses calon guru fisika, apakah terdapat perbedaan peningkatan keterampilan proses sains calon guru fisika pada kelas yang diterapkan pembelajaran inkuiri dan konvensional serta seberapa besar peningkatan keterampilan proses sains calon guru fisika setelah diterapkan pembelajaran inkuiri dan konvensional.

\section{METODE PENELITIAN}

Metode dalam penelitian ini adalah eksperimen dengan bentuk kuasi eksperimental dan rancangan nonequivalent control group design (Sugiyono, 2016). Adapun rancangan penelitian dapat dilihat pada Tabel 1.

Tabel 1. Rancangan Penelitian

\begin{tabular}{cccc}
\hline Kelas & $\begin{array}{c}\text { Pre- } \\
\text { Test }\end{array}$ & Perlakuan & $\begin{array}{c}\text { Post- } \\
\text { Test }\end{array}$ \\
\hline Eksperimen & $\mathrm{O}_{1}$ & Inkuiri & $\mathrm{O}_{2}$ \\
Kontrol & $\mathrm{O}_{3}$ & Konvensionsl & $\mathrm{O}_{4}$ \\
\hline
\end{tabular}


Berdasarkan Tabel 1, diketahui bahwa $\mathrm{O}_{1}$ dan $\mathrm{O}_{2}$ adalah pre-test dan post-test kelas eksperimen, $\mathrm{O}_{3}$ dan $\mathrm{O}_{4}$ adalah pretest dan post-test kelas kontrol dan $\mathrm{X}$ adalah perlakuan pada kelas eksperimen yaitu pembelajaran inkuiri. Sedangkan untuk kelas kontrol diberikan pembelajaran konvensional yaitu dengan ceramah dan tanya jawab.

Sampel dalam penelitian ini berjumlah dua kelas yang ditentukan dengan teknik purposive sampling. Pertimbangan pemilihan sampel dengan memperhatikan tingkatan akademik yang sama.

Teknik pengumpul data dalam penelitian ini adalah pengukuran dengan alat pengumpul data berupa tes keterampilan proses sains. Tes keterampilan proses sains yang indikatornya mengacu pada (Dimyati, 2002) yaitu mengobservasi, mengklasifikasi, memprediksi, mengukur, menyimpulkan dan mengkomunikasikan. Tes yang digunakan telah divalidasi oleh tiga validator dan telah dinyatakan layak digunakan.

Keterampilan proses sains calon guru fisika dianalisis menggunakan statistik deskriptif. Untuk mengetahui perbedaan peningkatan keterampilan proses sains dikelas eksperimen dan kontrol dilakukan pengujian statistik menggunakan SPSS 16 for windows. Peningkatan keterampilan proses sains calon guru fisika setelah diterapkan pembelajaran inkuiri dianalisis dengan gain ternormalisasi berdasarkan Persamaan (1) (Hake, 1998):

$$
g=\frac{\text { skor posttest }- \text { skor pretest }}{\text { skor maksimum }- \text { skor pretest }}
$$

Berdasarkan Persamaan (1), diketahui bahwa $g$ adalah nilai gain ternormalisasi (N-gain) yang kemudian diinterpretasikan untuk menyatakan peningkatan keterampilan proses sains. Adapun kriteria gain ternormalisasi disajikan pada Tabel 2.
Tabel 2. Kriteria Gain Ternormalisasi (N-gain)

\begin{tabular}{cc}
\hline$N$-gain & Interpretasi \\
\hline $0,7<\mathrm{g} \leq 1$ & Tinggi \\
$0,3<\mathrm{g} \leq 0,7$ & Sedang \\
$0 \leq \mathrm{g} \leq 0,3$ & Rendah \\
\hline
\end{tabular}

\section{HASIL DAN PEMBAHASAN Hasil Penelitian}

Analisis deskriptif keterampilan proses sains calon guru fisika di kelas eksperimen disajikan pada Tabel 3. Tabel 3 menunjukkan bahwa rata-rata keterampilan proses sains calon guru fisika pada kelas eksperimen sebelum diterapkan pembelajaran inkuiri adalah 27,38. Setelah diterapkan pembelajaran inkuiri rata-rata keterampilan proses sains calon guru fisika menjadi 65,47 . Hal ini menunjukkan bahwa secara umum terdapat peningkatan keterampilan proses sains calon guru fisika setelah diterapkan pembelajaran inkuiri dengan nilai gain sebesar 38,09.

Tabel 3. Keterampilan Proses Sains Calon Guru Fisika di Kelas Eksperimen

\begin{tabular}{lll}
\multicolumn{3}{c}{ di Kelas Eksperimen } \\
\hline & Pre-test & Post-test \\
\hline Nilai Min & 7.14 & 42,86 \\
\hline Nilai Max & 42,86 & 85,71 \\
\hline Standar deviasi & 12,86 & 15,17 \\
\hline Rata-rata & 27,38 & 65,47 \\
\hline Gain & & 38,09 \\
\hline
\end{tabular}

Analisis deskriptif keterampilan proses sains calon guru fisika dikelas kontrol disajikan pada Tabel 4. Tabel 4 menunjukkan bahwa rata-rata keterampilan proses sains calon guru fisika pada kelas kontrol sebelum diterapkan pembelajaran konvensional adalah 21,93. Setelah diterapkan pembelajaran konvensional rata-rata keterampilan proses sains calon guru fisika menjadi 39,79. Hal ini menunjukkan bahwa secara umum terdapat peningkatan keterampilan proses sains calon guru fisika setelah diterapkan pembelajaran konvensional dengan nilai gain sebesar 17,86. 
Tabel 4. Keterampilan Proses Sains Calon Guru Fisika di Kelas Kontrol

\begin{tabular}{lll}
\hline & Pre-test & Post-test \\
\hline Nilai Min & 0 & 7,14 \\
\hline Nilai Max & 50 & 64,29 \\
\hline Standar deviasi & 17,14 & 17,43 \\
\hline Rata-rata & 21,93 & 39,79 \\
\hline Gain & \multicolumn{2}{c}{17,86} \\
\hline
\end{tabular}

Berdasarkan analisis deskriptif data pada Tabel 3 dan Tabel 4, dapat disimpulkan bahwa terdapat peningkatan keterampilan proses calon guru fisika pada kelas eksperimen dan kelas kontrol. Namun peningkatan keterampilan proses sains pada kelas eksperimen lebih tinggi dibandingkan dengan kelas kontrol. Hal ini menunjukkan bahwa secara umum terdapat perbedaan peningkatan keterampilan proses sains calon guru fisika pada kelas yang diterapkan pembelajaran inkuiri dan konvensional.

Hasil uji prasyarat analisis menunjukkan bahwa uji normalitas sebaran data masing-masing variabel dengan perhitungan program SPSS 16 for windows Kolmogorov-smirnov angka signifikansi pada kelas eksperimen dan kontrol lebih besar dari 0,05 sehingga semua sebaran data berdistribusi normal. Sajian lengkap uji normalitas dapat dilihat pada Tabel 5.

\begin{tabular}{ll} 
Tabel 5. Uji normalitas & \\
\hline Kelas & Sig. \\
\hline Eksperimen & 0,542 \\
Kontrol & 0,426 \\
\hline
\end{tabular}

Uji homegenitas dilakukan terhadap kelompok data peningkatan keterampilan proses sains pada kelas eksperimen dan kelas kontrol. Hasil uji Levene's Test menunjukkan bahwa angka signifikansi yaitu 0,233 lebih besar dari 0,05 sehingga dapat disimpulkan bahwa variabel peningkatan keterampilan proses sains calon guru fisika pada kelas eksperimen dan kontrol homogen.

Karena data berdistribusi normal dan homogen maka selanjutnya dilakukan uji hipotesis menggunakan uji t-independent sample. Hasil uji t-independent sampel menunjukkan angka signifikansi yaitu 0,004 lebih kecil dari 0,05. Hal ini menandakan bahwa Ho ditolak dan $\mathrm{Ha}$ yang menyatakan bahwa "terdapat perbedaan peningkatan keterampilan proses sains calon guru fisika setelah diterapkan pembelajaran inkuiri dan pembelajaran konvensional", diterima.

Peningkatan keterampilan proses sains tersebut diukur dengan gain ternormalisasi (N-Gain) menggunakan Persamaan 1. Adapun N-gain ternormalisasi kelas kontrol dan eksperimen disajikan pada Tabel 6.

Tabel 6. N-Gain Ternormalisasi Kelas Kontrol dan Eksperimen

\begin{tabular}{ccc}
\hline Kelas & $N$-Gain $(g)$ & Interpretasi \\
\hline Eksperimen & 0,65 & Sedang \\
\hline Kontrol & 0,27 & Rendah \\
\hline
\end{tabular}

Berdasarkan Tabel 6, N-Gain ( $g$ ) pada kelas eksperimen adalah 0,65 dengan interpretasi sedang dan pada kelas kontrol adalah 0,27 dengan interpretasi rendah. Hal tersebut menunjukkan bahwa peningkatan keterampilan proses sains calon guru fisika pada kelas yang diterapkan pembelajaran inkuiri lebih baik dibandingkan kelas yang diterapkan pembelajaran konvensional. Adanya perbedaan tersebut menunjukkan bahwa pembelajaran inkuiri mampu meningkatkan keterampilan proses sains guru fisika.

Perbandingan skor post-test keterampilan proses sains setiap aspek pada kelas eksperimen dan kelas kontrol disajikan pada Gambar 1. 


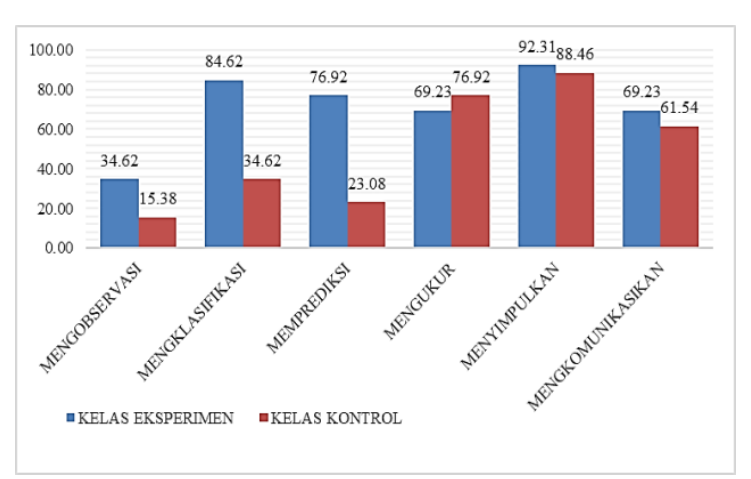

Gambar 1. Nilai Post-test Keterampilan Proses Sains Kelas Eksperimen dan Kelas Kontrol.

Berdasarkan Gambar 1 diketahui bahwa terdapat enam aspek kerampilan proses sains yang diukur baik pada kelas eksperimen maupun kelas kontrol. Secara umum nilai post-test keterampilan proses sains calon guru fisika lebih baik dialami pada kelas eksperimen. Namun ada satu aspek yaitu mengukur dimana kelas kontrol memperoleh nilai yang lebih baik dibandingkan kelas eksperimen. Hal ini terjadi dikarenakan beberapa mahasiswa yang kurang teliti dalam mengukur termasuk pada saat mengkalibrasi alat ukur.

\section{Pembahasan}

Keterampilan proses sains pada kelas eksperimen diasah melalui kegiatan pembelajaran inkuiri yang di dalamnya terdapat tahapan-tahapan yaitu orientasi, mengajukan permasalahan, merumuskan hipotesis, mengumpulkan data, menguji hipotesis dan membuat kesimpulan (Sanjaya, 2011). Dalam pembelajaran inkuiri yang diterapkan mahasiswa juga dibantu dengan Lembar Kerja Mahasiswa (LKM) yang di dalamnnya memuat tahapan-tahapan inkuiri. Pada tahap orientasi, calon guru fisika yang dalam hal ini adalah mahasiswa Program Studi Pendidikan Fisika IKIP PGRI Pontianak telah mampu mengenali (mengidentifikasi) masalah terkait penerapan Hukum Ohm dalam kehidupan sehari-hari melalui suatu sajian video.
Masalah yang telah teridentifikasi selanjutnya dirumuskan dalam suatu rumusan masalah. Berdasarkan permasalahan yang telah diajukan, mahasiswa diajak melanjutkan ke tahapan berikutnya yaitu membuat hipotesis. Untuk menjawab hipotesis yang artinya mahasiswa diberi kesempatan untuk memprediksi penyebab masalah yang muncul di awal kegiatan. Tahapan selanjutnya dalam inkuiri adalah pengumpulan data dan pengujian hipotesis. Kegiatan ini dilakukan melalaui sebuah eksperimen. Dalam kegiatan ini keterampilan proses sains yang diasah observasi, mengukur mengklasifikasi, dan menyimpulkan. Setelah mahasiswa selesai melakukan eksperimen, mahasiswa diminta untuk mempresentasikan hasil yang telah diperoleh dan kemudian dikaitkan dengan pemecahan masalah yang telah disampaikan di awal, pada tahap inilah keterampilan proses sains yaitu mengkomunikasika dilatih. Berdasarkan eksperimen yang telah dilakukan, maka mahasiswa telah dapat memecahkan masalah dan menemukan kebenaran hipotesis. Dari pembelajaran inkuiri yang telah dilakukan mahasiswa, terlihat bahwa kegiatan yang dilakukan melatih mahasiswa untuk melakukan kegiatan ilmiah untuk menemukan konsep. Mahasiwa memiliki kesempatan yang luas untuk menumbuhkan keterampilan proses sains melalui kegiatan penyelidikan seperti yang dilakukan oleh ilmuan. Hal ini sejalan dengan pernyataan (Wulanningsih, Prayitno, \& Probosar, 2012) yang menyatakan bahwa model pembelajaran inkuiri sangat sesuai untuk mengembangkan keterampilan proses sains, karena sintak atau tahap pembelajarannya dikembangkan dengan metode ilmiah yang dapat melatihkan keterampilan proses sains pada siswa.

Tidak hanya di kelas eksperimen, kelas kontrol juga melakukan berbagai bentuk kegiatan pembelajaran pada materi 
listrik dinamis dengan metode konvensional. Mahasiswa dilatih untuk menemukan masalah, mengajukan hipotesis, mengobservasi, mengklasifikasi, menyimpulkan dan mengkomunikasikan melalui latihan soal yang diselesaikan melalui diskusi kelompok dan tanya jawab. Kelas konvensional kurang melatihkan keterampilan proses sains pada mahasiswa karena dalam proses pembelajaran tidak melalui kegiatan penyelidikan seperti yang biasa dilakukan oleh ilmuan tetapi hanya mengerjakan latihan soal. Hal ini, tidak sesuai dengan (Karamustafaoğlu, 2011) bahwa siswa harus memiliki keterampilan proses sains yang bermanfaat bagi siswa untuk mampu berpartisipasi aktif dalam penyelidikan.

Memiliki keterampilan sains yang baik sangat penting bagi calon guru fisika. Hal ini sejalan dengan pernyataan (Hartati, 2010) pada penelitiannya menyebutkan kebermaknaan pembelajaran fisika terdapat pada proses mengamati, memahami, dan memanfaatkan gejala-gejala alam yang ada di lingkungan sekitar. Sehingga mahasiswa sebagai calon pendidik sudah seharusnya memliki keterampilan proses sains yang nantinya akan diajarkan kembali kepada peserta didik. Selain itu, proses pembelajaran fisika menekankan pada pemberian pengalaman langsung untuk mengembangkan kompetensi agar menjelajahi dan memahami alam sekitar secara ilmiah dan dilaksanakan secara inkuiri alamiah (scientific inquiry) untuk menumbuhkan kemampuan berpikir, bekerja dan bersikap ilmiah, serta mengkomunikasikannya sebagai aspek penting kecakapan hidup (Susilo et al., 2012). Oleh Karena itu, pembelajaran fisika sangat menekankan pada hal-hal yang bersifat proses, sehingga penguasaan konsep fisika calon guru tidak hanya berupa hafalan, tetapi mereka juga mampu menerapkan konsep yang dimilikinya pada aspek lain. Hal tersebut dapat dimunculkan salah satunya melalui keterampilan proses sains.

Hasil penelitian yang diperoleh relevan dengan beberapa penelitian sebelumnya. Berdasarkan penelitian yang telah dilakukan oleh (Setyawati, Candiasa, \& Yudana, 2016) diketahui bahwa rata-rata keterampilan proses sains siswa yang menggunakan model pembelajaran inkuiri terbimbing lebih besar daripada siswa yang menggunakan model pembelajaran konvensional. Sejalan dengan (Kurniawati, Masykuri, \& Saputro, 2016) penerapan model pembelajaran inkuiri terbimbing berbatuan LKS dapat meningkatkan keterampilan proses sains siswa pada materi hukum dasar kimia.

\section{SIMPULAN}

Berdasarkan hasil penelitian dapat disimpulkan bahwa peningkatan keterampilan proses sains calon guru fisika pada kelas yang diterapkan pembelajaran inkuiri lebih baik dibandingkan dengan kelas yang diterapkan pembelajaran konvensional. Peningkatan (gain) keterampilan proses sains pada kelas yang diterapkan pembelajaran inkuiri adalah 38,09 sedangkan pada kelas yang diterapkan pembelajaran konvensional adalah 17,86. Hasil uji $t$ independent sampel menunjukkan angka signifikansi yaitu 0,004 lebih kecil dari 0,05. Hal ini menandakan bahwa $\mathrm{H}_{0}$ ditolak dan $\mathrm{H}_{\mathrm{a}}$ diterima sehingga terdapat perbedaan peningkatan keterampilan proses sains calon guru fisika di kelas yang diterapkan pembelajaran inkuiri dan konvensional. $\mathrm{N}$-Gain $(\mathrm{g}$ ) pada kelas eksperimen adalah 0,65 dengan interpretasi sedang dan pada kelas kontrol adalah 0,27 dengan interpretasi rendah. Adanya perbedaan tersebut menunjukkan bahwa pembelajaran inkuiri mampu meningkatkan keterampilan proses sains guru fisika. 


\section{UCAPAN TERIMA KASIH}

Ucapan terimakasih kepada Ristek Dikti atas dukungan pembiayaan SK. Jenderal Penguatan Riset dan Pengembangan Nomor 01/E/KPT/2017.

\section{DAFTAR PUSTAKA}

Dimyati, M. (2002). Belajar dan Pembelajaran. Jakarta: PT Rineka Cipta.

Ertikanto, C. (2017). Perbandingan Kemampuan Inkuiri Mahasiswa Pendidikan Guru Sekolah Dasar dalam Perkuliahan Sains. Jurnal Ilmiah Pendidikan Fisika Al-Biruni, 6(1), 103.

Hake, R. R. (1998). Interactiveengagement Versus Traditional Methods : A Six-thousand-student Survey of Mechanics Test Data for Introductory Physics Courses. American Journal of Physics, 66(64), 64-74.

Hardiyanto, Susilawati, \& Harjono, A. (2015). Pengaruh Model Pembelajaran Berbasis Masalah dan Ekspositori dengan Keterampilan Proses Sains terhadap Hasil Belajar Fisika Siswa Kelas VIII MTsN 1 Mataram Tahun Ajaran 2014/2015. Jurnal Pendidikan Fisika Dan Teknologi, 1(4).

Hartati, B. (2010). Pengembangan Alat Peraga Gaya Gesek untuk Meningkatkan Keterampilan Berpikir Kritis Siswa SMA. Jurnal Pendidikan Fisika Indonesia, 6, 128-132.

Jannah, L., Nur, M., \& Suyono. (2016). Desain Bahan Ajar Materi Gelombang dan Bunyi Model Inkuiri Terbimbing untuk Melatihkan Keterampilan Proses Sais Siswa SMP. Pendidikan Sains Pascasarjana Universitas Negeri Surabaya, 6(1), 1196-1203.

Karamustafaoğlu, S. (2011). Improving The Science Process Skills Ability of Science Student Teachers Using I
Diagrams. Eurasian Journal of Physics and Chemistry Education, 3(1), 26-38.

Komikesari, H. (2016). Peningkatan Keterampilan Proses Sains dan Hasil Belajar Fisika Siswa pada Model Pembelajaran Kooperatif Tipe Student Team Achievement Division. Jurnal Keguruan Dan Ilmu Tarbiyah, 1(1), 15-22.

Kurniawati, D., Masykuri, M., \& Saputro,

S. (2016). Penerapan Model

Pembelajaran Inkuiri Terbimbing Dilengkapi LKS untuk Meningkatkan Keterampilan Proses Sains dan Prestasi Belajar pada Materi Pokok Hukum Dasar Kimia Siswa Kelas X MIA 4 SMA N 1 Karanganyar Tahun Pelajaran 2014/2015. Jurnal Pendidikan Kimia, 5(1), 88-95.

Lestari, I. A. P. M., Suniasih, N. W., \& Putra, I. K. A. (2016). Penerapan Model Pembelajaran Inkuiri Berbasis Portofolio untuk Meningkatkan Hasil Belajar IPA Siswa Kelas V. EJournal PGSD Universitas Pendidikan Ganesha, 4(1), 1-10.

Rerung, N., Sinon, I. L. S., \& Widyaningsih, S. W. (2017). Penerapan Model Pembelajaran Problem Based Learning (PBL) untuk Meningkatkan Hasil Belajar Peserta Didik SMA pada Materi Usaha dan Energi. Jurnal Ilmiah Pendidikan Fisika Al-Biruni, 6(April), 47-55.

Sanjaya, W. (2011). Strategi Pembelajaran Berorientasi Standar Proses Sains PEndidikan. Jakarta: Kencana.

Saregar, A. (2016). Pembelajaran Pengantar Fisika Kuantum Dengan Memanfaatkan Media Phet Simulation Dan Lkm Melalui Pendekatan Saintifik: Dampak Pada Minat Dan Penguasaan Konsep Mahasiswa. Jurnal Ilmiah Pendidikan Fisika Al-Biruni, 5(1), 
53-60.

Saregar, A., Latifah, S., \& Sari, M. (2016). Efektivitas Model Pembelajaran CUPs: Dampak terhadap Kemampuan Berpikir Tingkat Tinggi Peserta Didik Madrasah Aliyah Mathla'ul Anwar Gisting Lampung. Jurnal Ilmiah Pendidikan Fisika Al-Biruni, 5(2), 233-243.

https://doi.org/10.24042/jpifalbiruni. v5i2.123

Setyawati, N. W. I., Candiasa, M., \& Yudana, I. M. (2016). Pengaruh Model Pembelajaran Inkuiri Terbimbing terhadap Pemahaman Konsep dan Keterampilan Proses Sains Siswa Kelas XI IPA SMA Negeri 2 Kuta Kabupaten Bandung. E-Journal PGSD Universitas Pendidikan Ganesha, 4(1), 1-10.

Sohibun, Febriani, Y., \& Maisaroh, I. (2017). Peranan Mata Kuliah Profesi Kependidikan dan Microteaching terhadap Kompetensi Profesional Mahasiswa PPL Fisika. Tadris: Jurnal Keguruan Dan Ilmu Tarbiyah, 2(1), 53-61.

Susilo, A. B., Wiyanto, \& Supartono. (2012). Model Pembelajaran IPA Berbasis Masalah untuk Meningkatkan Motivasi Belajar dan Berpikir Kritis Siswa SMP. Unnes Science Education Journal, 1(1), 1220.

Syamsu, F. D. (2017). Pengembangan Penuntun Praktikum IPA Berbasis Inkuiri Terbimbing untuk Siswa SMP Siswa Kelas VII Semester Genap. BIOnatural, 4(2), 13-27.

Wahyudin, Sutikno, \& Isa, A. (2010). Keefektifan Berbantuan Pembelajaran Menggunakan Metode Inkuiri Terbimbing untuk Meningkatkan Minat dan Pemahaman Siswa. Jurnal Pendidikan Fisika Indonesia, 6, 5862.

Wati, W., \& Fatimah, R. (2016). Effect
Size Model Pembelajaran Kooperatif Tipe Numbered Heads Together (NHT) terhadap Kemampuan Berpikir Kritis Siswa pada Pembelajaran Fisika. Jurnal Ilmiah Pendidikan Fisika Al-Biruni, 5(2), 213-222. https://doi.org/10.24042/jpifalbiruni. v5i2.121

Wulanningsih, S., Prayitno, B. A., \& Probosar, R. M. (2012). Pengaruh Model Pembelajaran Inkuiri Terbimbing terhadap Keterampilan Proses Sains Ditinjau dari Kemampuan Akademik Siswa SMA Negeri 5 Surakarta. Pendidikan Biologi, 4(2), 33-43.

Yamin, M. (2016). Peningkatan Hasil Belajar dan Aktivitas Matematika Siswa Melalui Strategi Pembelajaran Inkuiri pada Kelas XII IPA-2 SMAN 2 Bagan Sinembah Tahun Pelajaran 2014/2015. Jurnal EduTech, 2(1), 65-71. 